\title{
SHIFT-SHARE ANALYSIS OF PRODUCTION IN THE MANUFACTURING INDUSTRY OF SOUTH AFRICA'S SOUTHERN DISTRICT MUNICIPALITY
}

\author{
Ewert Kleynhans* \\ North-West University \\ Ewert.Kleynhans@nwu.ac.za \\ Moloto J Sekhobela \# \\ Department of Trade and Industry
}

MSekhobela@thedti.gov.za

May 2010

\section{Abstract}

In this study, the development and structure of value-added production in the manufacturing industries of the Southern District Municipality (SDM) of South Africa are investigated. The field of study focuses on spatial economic development, with the aim of identifying industries that can offer future growth and job creation. The methodology of shift-share analysis, often applied to studies of Economic Geography, is used for the empirical analysis. The SDM district municipality includes the local municipalities of Klerksdorp, Potchefstroom, Ventersdorp, Merafong City and Wolmaransstad. The economy of these municipalities is mainly dependent on gold mining, which is declining as their gold reserves are becoming depleted which will lead to a large section of its population being unemployed in the near future. Shift-share analysis provides insight into the shifts of production between various sectors over time and is comprehensible to policymakers. It provides further insight into the national share effect on production of the sectors in the region, as well as the regional industrial mix and the competitive share effects. It was found that the sectors with the highest growth potential are Transport Equipment, Petroleum and Chemicals, Furniture, Metal Products, and Wood and Paper Products, and they merit attention in future development initiatives.

\section{Keywords}

Economic geography, spatial development, industrial development, shift-share analysis, South Africa, Southern District Municipality

\footnotetext{
* Prof Ewert Kleynhans is an associate professor in the school of Economics at Potchefstroom Campus of North West University, South Africa.

\# Mr Moloto Johannes Sekhobela is an economist in the Office of the Deputy Director General, The Enterprise Organisation, Department of Trade and Industry (DTI), South Africa.
} 


\section{INTRODUCTION}

The objective of this study was to identify industries that have the potential for future growth in the Southern District Municipality (SDM) of South Africa. The area is mainly dependent on the mining industry and as the goldmines in the area are becoming exhausted, the area is bound to suffer large-scale unemployment and low economic growth in future. It is therefore important to find alternative means of development for the region in time.

The field of research of Economic Geography is concerned with the development and spread of economic entities across space. It studies economic activities and dynamics relevant to specific geographical areas. This particular study investigates the relevant shares and shifts of labour and production in and between towns and the various sectors of manufacturing, considering the relevant economic indicators for the decade starting from 1996. The article addresses the problem of employment creation in the area, trying to find some solutions. Academically, it is particularly constructive to Development Economics, Economic Geography, and Regional and Town Planning, illustrating how spatial economic development can be directly applied in practice.

The research methodology that was utilised is based on shift-share analysis, often applied in studies of Economic Geography (see, for example the Office of Social and Economic Trend Analysis (SETA) - website given in the bibliography; and Mayor \& López, 2008). The method was satisfactorily applied to study the research problem empirically. The lack of data and data restrictions often present large problems for studies on the micro level, such as towns, and this analysis method could be applied effectively to the available data. The method was also chosen because the method and results are easily understood and interpreted by policymakers and politicians - which is often a problem, leading to much criticism from economists and econometricians (Maia, 2009).

The Rex database obtained from the Global Insight data company (2007) was used for the empirical study, because it provided the relevant data broken down into municipality and magisterial level. The database provides not only national data of indicators, like employment and gross value added, but also detail on province and town, including a breakdown of the various sub-divisions of manufacturing, for example basic metals, food and beverages, and electrical machinery. To obtain the specific data on the Southern District Municipality, the data of the various municipalities (managerial districts), which the SDM consists of, was totalled.

The article will firstly describe the decline of gold production and then explain why manufacturing is considered an engine of growth. Thereafter, the empirical identification of potential manufacturing sectors is analysed, considering the production output performance of the various sub-sectors in the region, as well as the influence that the national factors, the industrial mix of the area, and the regional competitive share effects have on production in the area. Growing and declining sectors are identified to predict changes in economic growth and to analyse the sectors that contribute most to employment creation and therefore growth. This will be compared to the results of a similar study that was conducted, which considered production in the region. A comparison between the national and provincial analyses is also being done to ensure that the results were significant and to determine the implications of the results for the Southern District Municipality. The final section will provide a summary and conclusion.

The following section will consider the problem of the declining production of gold in the area. 


\section{THE DECLINE OF GOLDMINES IN THE SDM}

The Southern District Municipality (SDM) is located on the south-eastern border of the North West Province of South Africa. The locations of the various district municipalities in the province are illustrated on Map 1. The SDM is a larger district municipality consisting of the five local municipalities of Klerksdorp (also known as Matlosana), Potchefstroom, Ventersdorp, Merafong City and Maquassi Hills (Wolmaransstad area) - see Map 2. The SDM's economy is largely dependent on mining and to some extent on agriculture and manufacturing (Stats SA, 2006:12). The mining industry in this area has several linkages with other industries, like the engineering firms, which maintain the metal and plastic structures and mills, and the agricultural, food and beverages sectors, which provide food for the mineworkers and supporting industries. When mining declines, all these other industries also decline and the whole economy moves into recession.

The SDM region is dependent on mining, but mines have a limited lifespan and most of them are closing down, which affects the employment and economic growth of the region in a negative manner. Dyason (2005:81) already confirmed this in 2005 when he asserted that the negative GDP growth rate in Klerksdorp (a city in the SDM with the highest number of economically active people) is mainly due to the decline in mining activity and the diminishing role that mining is playing in the South African economy.

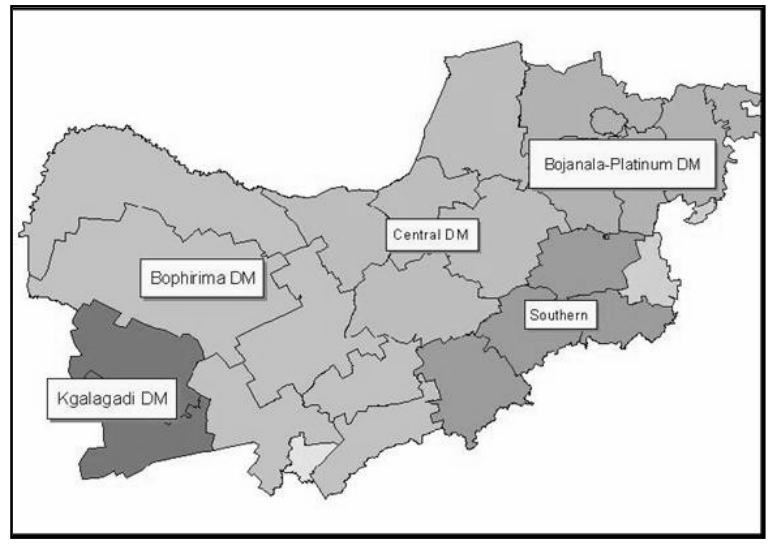

\section{Map 1: District Municipalities of the North West Province}

Source: Stats SA, 2006

The Chamber of Mines (2005:25) also confirmed that gold production is steadily declining in South Africa. Production has declined steadily since 1996, decreasing $60.1 \%$ over the last decade. This means that South African gold has also diminished as a percentage of total world production. The viability of the mining sector has also been undermined by the low gold price, high input costs and the restructuring of certain operations, especially during the first half of 2005. Gold production declined by $13.1 \%$ to 297.3 tonnes, the lowest level of production since 1923 (The Chamber of Mines, 2005). Comparing the gold production of July 2007 with July 2006, a decline of $5.2 \%$ was registered by the industry (Stats SA, 2007:6) and between April and May 2009 , for example, it declined by $4.8 \%$. Gold production from January 2008 compared to January 2009 declined by $12.2 \%$ (Stats SA, 2009:3) and during 2009 it declined by a further $11.1 \%$ (Stats 
$S A, 2010: 9)$.

As gold production deteriorates, employment, economic growth and development have also declined in the region. The number of mineworkers decreased from 342439 in 1996 to 137611 in 2005, which represents a decline of $40 \%$ (Chamber of Mines, 2005:28). The closing of two mines in Stilfontein, located in the Southern District Municipality, during 2005, for example, caused job losses for 6500 mineworkers. After Simmer and Jack Mines Ltd bought these mines later that year, the mines reopened, but re-employed only 3000 people (Jansen, 2007:30). This meant that more than $46 \%$ of those who lost their jobs remained unemployed.

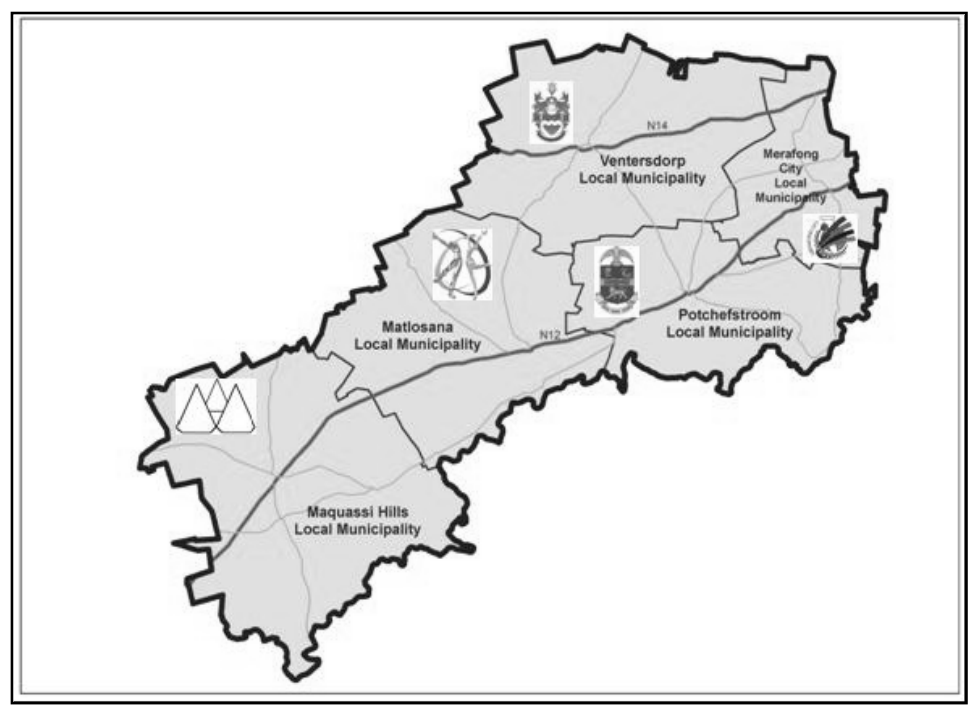

\section{Map 2: Southern District Municipality}

\section{Source: Southern District Municipality, 2007}

As gold mining is declining in the area, other sectors need to be developed to answer to the future pressures of unemployment, low growth and other developmental needs in the area. This study wishes to contribute to the identification of industries that offer potential.

A literature study of the state of affairs revealed that manufacturing industries might be considered as a possible engine of growth. Some researchers suggest that manufacturing could curb the decline in employment opportunities and lead to growth (Kleynhans \& Drewes, 2008:1). During his research on the south-eastern provinces of China, Golley (2002:780) found that above-average performance in manufacturing led to industrial agglomeration and growth, which led to higher economic growth rates and per capita GDP. This highlights the importance of gross value added and is the reason it was utilised in the study of the SDM. Manufacturing in Mexico also responded favourably where chains of industrial clusters and location-specific initiatives existed between 1990 and 2002 (Mollick, Cortez-Rayas \& Olivas-Moncisvais, 2006:114).

Currently, only $3.2 \%$ of the SDM workforce is involved in manufacturing industries, given that diversification of the economic structure in the region should occur in order to improve the economic outlook of the regions (Dyason, 2005:81). Labour force growth is, according to Armstrong and Taylor (2000:114), one of the determinants of output growth in manufacturing 
and since some industries have more growth potential than others, the particular mix of industries in which a region specialises has an effect on the region's growth performance.

Knowledge concerning growth trends will assist in the understanding of employment patterns at regional level. According to Shearmur and Polèse (2007:454), smaller and more-specialised regions need employment opportunities in order to survive. There is no evidence to suggest a straightforward and unique approach to employment creation and retention at local level. However, research has shown that slow-growing areas are usually more specialised in declining industries that are primary and first-transformation manufacturers (Shearmur \& Polèse, 2007:453-461).

The mineral base of South Africa is depleting and this will have a significant effect on the spatial economy of South Africa in future. The five local municipalities of the SDM are among the first to experience the consequences of mines closing down. It is still restricted to particular areas, but in time more mines will end production and the unemployment and poverty it causes will lead to political unrest and migration to other areas. Creation of new employment opportunities in a sustainable manner is therefore of the utmost importance. Various development strategies of the Southern African landscape are currently followed, like Spatial Development Initiatives for example (Kleynhans, Naudé \& Van der Merwe, 2003:716), as well as increasing the production of other industries, diversification and export promotion. This paper focuses on the promotion of sustainable industrial production and export, with the identification of possible industries that have the potential to achieve this.

The following section illustrates the theoretical linkages between shift-share analysis and Spatial Economics.

\section{THEORETICAL ASPECTS OF SPATIAL \&CONOMICS}

The academic relevance to Classical Economics can be shown if one accepts that economic wealth is highest where the factors of production are as free and mobile as possible. Shift-share shows the movement of economic activity and the shifts and shares between regions, as the economic geography develops through time (Mankiw, 2007:410). Even though shift-share analysis has no theoretical basis, it fits into most Spatial Economic models of Town and Regional Planning, as well as Economic Geography.

Shift-share analysis can be applied to nearly all economic theories, especially those with a spatial base. The method itself does not require a theoretical base because, quite similar to location quotients, it calculates directly what is required. It determines various averages, estimated in various ways to indicate spatial shifts and shares of economic entities, such as growth and employment figures. Weber (1929:49) was one of the first to model economic development in a spatial context, determining factors of location and the influence of labour and consumption growth around specific regions (Kleynhans \& Drewes, 2008:2). The Von Thünen theory states that products, which achieve the highest profits, will outbid all others in the competition for location (Wheeler \& Muller, 1998:318). His theory states that the higher the transport costs, the lower the amount that a producer would be willing to pay to use the land. Competition causes land rent to decline from a maximum at the market (town) to zero at the outermost limit of civilisation. This result in a pattern of concentric rings of production around the market with perishable vegetables in the ring close to the market followed by wheat and cattle ranches furthest away, because of rising transport costs. In urban settings, land values 
also increase with increasing access to important destinations such as places of shopping and work (Wheeler \& Muller, 1998:328-330). Von Thünen's market forces and patterns of land use can today also be observed at a continental or global scale (Fujita, Krugman \& Venables, 2001:15), and the specific regional shares, contribution due to industrial mix, and competitive impact of a region can be estimated using shift-share analysis.

Isard already selected optimum manufacturing sites during 1949 by evaluating the substitution of expenditure of the various factors of production (see e.g. Isard \& Liossatos, 1997). This analysis is similar to micro-economic analysis utilising indifference curves or isoquants. Lösch (1954:27) noted that the correct location is where the manufacturer maximises its net profits, but he largely ignored costs in his maximisation approach to industrial location and overemphasised demand and sales (Chapman \& Walker, 1991:39).

Once a concentration of industry is established, it is profitable for new producers to follow, making agglomeration self-sustaining because transaction costs increase across distance and this forms part of the profit maximising behaviour of firms (Krugman, 1991:98). At a growth pole, centrifugal and centripetal forces are generated and the forces from nearby are strongest and will lead to a special displacement of economic activity to those regions. This can be modelled using shift-share analysis. Fujita, Krugman and Venables (2001:131, 166) studied the spatial economy of urban systems, integrated the models of Von Thünen and Lösch, and developed mathematical models that differentiated groups of commodities between different cities.

These are just a few examples to illustrate how shift-share analysis can link to various economic theories. The following section explains why the shift-share analysis methodology was chosen and what it entails, mostly based on a literature study and practical considerations.

\section{THE SHIFT-SHARE ANALYSIS METHODOLOGY}

The intention of this section is to make a literature study of shift-share analysis to indicate the importance of this study and dictate a research programme for further study. This section discusses shift-share analysis and the research that utilises this method.

The appropriate empirical method chosen for this project was shift-share analysis, because it is a straightforward and speedy analytical technique, which utilises little data and can easily be understood by people outside economics, like politicians and policymakers. Data is often a problem and this technique can be applied to the Rex database of Global Insight with ease. It shows movements and shares of economic variables on various levels, down to magisterial level, enables differentiation between these regions, and provides additional information on the causes of the shifts and relative shares of employment or production within a spatial context.

Mayor and López (2008:124) define shift-share analysis as a statistical tool allowing the study of regional development by means of the identification of various factors. The classical shiftshare approach analysis, used in this study, determines the evolution of an economic magnitude between two periods, identifying three components, namely a national growth effect, a sectoral industrial mix effect and a regional competitive share effect. The methodology focuses on the dependence of the regions in question with regard to national evolution (Fernández \& Menéndez, 2006:2).

It was introduced as a descriptive device and a technique for systematically examining regional 
economic data - especially manufacturing. Shift-share analysis was first published in 1960 by Perloff et al. and Dunn used it in a paper read at a meeting of the Regional Science Association during that year (Stevens \& Moore, 1980:421).

This method determines the extent to which the industrial composition of a region is responsible for the difference in the employment growth rate and/or economic growth. In principle, the national growth rate per industry is applied to a region's industrial mix, starting from a particular base year (Armstrong \& Taylor, 1993:145). In this way, hypothetical growth rates are calculated for a region.

Shift-share analysis is a widely-used methodology in regional and urban research (Graham \& Spence, 1998:516). The Social and Economic Trend Analysis office (SETA) in the USA, for example, has a shift-share calculator, which analyses data for any state, city or county in America, which is then utilised in community and regional planning and management (SETA, 2008). Kobayashi and Roper (2004:430) regard shift-share analysis as a method to measure the effect of the industry mix and regional share between the growth of a region and the national growth rate. Shift-share analysis is often utilised in disciplines like Economic Geography, Spatial Economics and Regional and Urban Planning to analyse and examine, inter alia, employment changes, and it is a simple tool for disaggregating the various components of employment growth (Peh \& Wong, 1999:322).

Shift-share analysis is, however, often criticised for its weak theoretical foundation and equivocal empirical support (Stevens \& Moore, 1980:419, 422). Ray (1995:26), Patterson (1991:214), and Graham and Spence (1998:516) criticise shift-share analysis for being atheoretical and unable to demonstrate causality. It is alleged that it decomposes employment changes into various components, but cannot determine the cause of regional employment growth and it cannot guarantee or test the separation of the national, industrial and regional variables into statistically independent variables. The authors of this paper do not necessarily agree with these points of criticism, as the analysis is based purely on averages of location. It was noted above that this methodology can probably be seen as part of classical economics. It is a straightforward method that does not need any theoretical backing, calculating what is needed directly.

It is sometimes alleged that shift-share analysis is a measuring tool rather than an analytical technique. In this study, this analysis is applied specifically for this "tool's" ability to measure the intended growth rates. It is justifiable on pragmatic grounds as it enables quick, rough, but reasonably accurate and easily interpretable short-run projections.

This methodology can be applied to a wide range of situations, and various variations exist in the available literature. Stevens and Moore (1980:420) objected that literature on shift-share analyses is difficult to follow. It does not follow a standard set of mathematical definitions, terms or equations. This is, however, an indication of the value of the technique and its wide and valuable range of applicability.

Hellman (1976) tried various equations, for example, and found a difference in the accuracy of predictions between export industries and other local market-orientated markets. He also tried populations in some of the employment growth estimates and obtained better results.

Stilwell (1969) ascertained that a favourable industrial mix (M) is usually found in regions that have their employment concentrated in industries that are growing rapidly in the nation as a whole. The regional share $(R)$ component is usually smaller than the industrial mix $(M)$ component of any individual industry, and usually smaller than the industrial mix $(M)$ and 
competitive share $(\mathrm{S})$ components combined.

Esteban-Marquillas (1972) and Rosenfeld (1959) questioned the difference between regional production growth due to comparative advantage, as well as the relative degree of industrial specialisation. They also suggested the further disaggregation of the regional shift component, and introduced a concept called "homothetic employment", which is defined as the change in regional employment expected in an industry if the employment structure of a region were similar to that of the nation, and studied deviations from it.

In his models, Hellman (1974) includes an index of agglomeration economies in each industry (Stevens and Moore, 1980:426). Borts and Stein (1964) found that industries that enjoyed particular employment growth in a region might generate spatial agglomeration economies, which may increase regional advantage (Stevens \& Moore, 1980:429). Regions that gained a share larger than national growth contain production industries that enjoy competitive advantage, relative to other regions (Ashby 1964; Brown, 1969). It is reasonable to assume that such trends are likely to persist for forecasting purposes (Stevens \& Moore, 1980:429).

Some authors, such as Hewings (1976), and Nazara and Hewings (2004), recognised the convenience of considering spatial dependence between spatial units by means of the definition of a spatial weights matrix (as illustrated by Fernández \& Menéndez, 2006:2). This led to a more realistic approach to the evolution of production and/or employment. The increasing availability of data, together with the development of spatial econometric techniques, also enabled Fernández and Menéndez (2006:3) to incorporate spatial effects in shift-share analysis. This offered a wide variety of possibilities in regional analysis when they applied spatial econometrics techniques (Fernández \& Menéndez, 2006:20). The introduction of a spatially modified competitive effect by Fernández and Menéndez (2006) can be useful in understanding the effects of some regional policies on employment and production output growth, which has a simultaneous effect on neighbouring regions.

It must be emphasised that these procedures have certain limitations, mainly related to their deterministic character and to the arbitrariness inherent in considered spatial relations. Therefore, further research needs to be carried out, including both stochastic formulation and an exhaustive study of the spatial weights matrices.

Bendavid-Val (1993:67) regards shift-share analysis as a tool in identifying opportunities for altering the composition of regional economies in order to find a means to improve their performance. James and Hughes (1973) used shift-share analysis as a predictive tool. They used time-series annual employment data and made estimates with regression analyses, in an attempt to predict employment by state and industry. When James and Hughes decomposed the mean square error, it was revealed that most of the error they found was due to incomplete covariations. This is a serious weakness of most of their predictive models (Stevens \& Moore, 1980:425). Zimmerman (1975) included a term based on polynomial projections and smoothed time series over several years. He employed shift-share as a method for disaggregating forecasts for larger regions into forecasts for smaller spatial units.

There is a continuous debate concerning the forecasting ability of shift-share analyses. In 1973 James and Hughes did some tests evaluating shift-share analysis as a predictive method, applying it to both industries and states.

Regarding the static shift-share model, Dinc and Hayes (2005:376) made the assumptions that the regional technology, labour and demand patterns are similar to reference area, and ignored international and interregional trade (Kleynhans \& Sekhobela, 2009:16). Mayor, López and Pérez 
(2007:545) criticised these assumptions as being too idealistic and remote from practical situations. Wilson, Chern, Ping and Robinson (2005:165) also stress the method's inability to capture changes in the intermediate stages, between the initial and final periods. One solution to this problem is to divide the research period into more periods and to compare these intervals.

In the current study, shift-share analysis is utilised to determine, among other things, how well the regional mix of industries is performing, identifying the best performers, the region's competitiveness, as well as determining the performance of the individual industries. It can also be used to analyse an individual industry and the economy as a whole. The unexplained residual component is part of the regional competitive growth that contains region-specific factors. If it is positive, the region is growing faster than its industrial structure would predict. When this component is negative, industrial growth is below the industrial structure's potential (Lann, 2005).

Various studies on shift-share analysis have been criticised by Van der Merwe (2006:7) for lacking consistency in notation, definitive equations and terminology. Shift-share analysis remains a useful tool for policymakers, however, as it assists in the interpretation of, among other things, the changes in the industrial structure of their economies (Wilson et al., 2005:164), as well as the spatial economy of urban systems (like Fujita, Krugman \& Venables, 2001). Restrictions on data availability, especially on local municipal level, make the application of shift-share analysis ideal for this study, by making use of the Rex database. Although the shiftshare analysis method can be criticised, it was preferred in this study as it summarised and identified specific factors that address the research question.

The current study employs a combination of the notation, equations and approaches from Bendavid-Val (1993), Van der Merwe (2006) and Lann (2005). There were adopted to suit the requirements of this study. The economic growth in the region is disaggregated into three components, namely the national share effect $(N)$, industry mix effect $(M)$ and the regional competitive share effect (S). According to Mayor and López (2008:125), the total change in regional value-added production $(R)$ may be represented by the sum of these three components, thus:

$$
R=N+M+S
$$

The total size of production added or lost in the region, as a net effect of national growth, the industry mix and regional characteristics, is represented by the variable R. The potential growth of the region is represented by $N$, assuming that the production volumes of the region are growing at the national average growth rate, while $M$ is the proportion of regional production among faster-and slower-growing regional sectors relative to the national average growth rate, while $S$ describes how sectors in the region perform relative to the national averages of the same sectors.

The following section pays attention to the empirical study that was conducted on the various manufacturing industries in the Southern District Municipality (SDM) of South Africa. The section considers changes in national production output (determined by the Value Added production, expressed in the South African currency, the Rand, times 1000 ), the national share effect $(N)$, the industry mix $(M)$, the regional competitive share $(S)$, and the total change in regional production $(R)$. The specific methodology that was followed at each step will be explained as the results unfold. 


\section{EMPIRICAL RESULTS}

The objective of this study was to identify manufacturing sectors in the Southern District Municipality that have growth potential in production output, measured as gross value added, because of the threat of goldmines scaling down and several closing down. This presents possible future recessions and unemployment in the area. Gross Value Added (GVA) can be defined as a measure of the value of the goods and services produced in an economy and the GVA is primarily used to monitor the performance and well-being of economies. The difference between Gross Value Added (GVA) and Gross Domestic Product (GDP) is mainly that Gross Value Added excludes taxes and subsidies. Global Insight (2007) constructed GVA figures for the Rex database mainly using data from the South African Reserve Bank.

\subsection{National and regional growth}

In order to determine the National Share Effect, the growth rates between values added during 1996 and 2006 were determined. Firstly, the values in the total value produced during 1996 were subtracted from the production in 2006, which gave the growth in production in absolute terms, and then the growth rates thereof were calculated. This was done for the ten sub-sectors of production in South Africa and for the country as a whole. Then it was repeated for those municipalities in the SDM. This meant that the totals of the individual municipalities in the SDM had to be summarised first.

The national average growth rates in gross value added were thus determined first, then the total change in regional production $(R)$, followed by its percentage change in the region's gross value added $R$ (\%).

The national average growth in production in the research period was calculated to be $34 \%$. This percentage equals production worth 48805083 (× 1000 South African Rand). National sectors whose production grew in the range between $50 \%$ and $70 \%$ were electrical machines, petroleum and chemicals, and transport equipment. The highest growth rate of $66 \%$ was recorded in the transport equipment sector, while electrical machines grew only $50 \%$, the lowest in this aboveaverage range. Below-average growers were furniture (36\%), followed by metal products, and wood and paper products. The worst national sectors were textile and clothes $(17 \%)$, food and beverages $(11 \%)$, other non-metal minerals $(6 \%)$ and electronic equipment, which grew by only $4 \%$. Considering that the South African economy initially developed from an agricultural and mining economy, the low growth rates in food and beverages and mineral sectors are most disappointing.

On a regional level, regional gross value added at constant year 2000 prices $(\times \mathrm{R} 1000)$ in the SDM for the period 1996 to 2006 averaged a growth rate of minus $2 \%$, which represents a decline of 18537 ( $\times \mathrm{Rl} 000)$ in production. Six of the ten sectors, namely metal products, textile and clothes, wood and paper, food and beverages, other non-metal minerals and electronic equipment, registered negative growth rates - five of them below the region's average growth rate of minus $2 \%$

The lowest growth rate in the SDM of minus $27 \%$ was also recorded in the electronic equipment sector, followed by other non-metallic products $(-22 \%)$, food and beverages $(-11 \%)$, textile and clothes, as well as wood and paper products (both $-5 \%$ ), whereas metal products grew by only minus $1 \%$. The remaining four of the ten sectors - furniture, petroleum and chemicals, electrical machines and transport equipment - have positive growth rates, albeit below $25 \%-$ 
ranging from $5 \%$ in furniture to the highest growth rate of $22 \%$ in the sector for transport equipment.

The sectors with negative growth together lost a total of 49307 in production, whereas the positive growing sectors accounted for an increase of $30770(\times \mathrm{Rl} 000)$ in production, hence the total change in regional gross value added was minus $18537=[-49307+30770]$. This then indicates a decline in production of minus two\%. In comparison, all the national sectors grew positively, whereas the regional sectors had a mix of positive and negative growth rates. The national average production growth rate was positive, while the regional average production growth rate was negative.

The next section explains why differences occur between regional and national production growth rates.

\subsection{The National Share Effect (N)}

The National Share Effect is an indicator of how much regional gross value added would have grown had each of its sectors, and therefore the regional total, grown at the same rate as the national average gross value added growth rate. The National Share effect $(\mathrm{N})$ is determined by:

$$
\mathrm{N}=\sum_{\mathrm{k}=1}^{\mathrm{n}} \mathrm{e}_{\text {tok }}[\mathrm{E} \%]
$$

where $\mathrm{N}$ is the total national share of the manufacturing industry, $\mathrm{e}$ is the regional gross value added in sectors $1,2 \ldots n$ in the initial period to, and $\varepsilon \%$ is the national average gross value added growth rate.

Each sector's national share effect is determined as the initial production times over the total economic growth rate in the country, which in this case was $34 \%$. For example, the petroleum and chemicals industry in the SMD region delivered value-added production worth R163 316 million, and a $34 \%$ growth over this period would have been $34 \%$ of R163 316 million = R55 527 million in 2006. However, it was only 17334000 , implying a decline of 17964 (× R1 000).

The national share effect $(\times \mathrm{Rl} 000)$ in the Southern District Municipality for the period 1996 to 2006 is summarised in TABLE 1 . The national share effect shows by how much regional production would have grown had each of its sectors and the regional total grown at the same rate as the national average production growth rate of $34 \%$, in this case. The national share effect of production is calculated using equation (equation 2). From TABLE 1 , the total national share effect is 296464 . This is the production the region would have achieved in the research period had the region been growing at the national average growth rate of $34 \%$.

The actual regional growth is minus 18537 and implies a loss of production to the abovementioned value. The difference of minus 315001 , between the national share and the total change in regional value added $(R-N)$, is due to the industrial mix $(M)$ and the regional competitive share $(S)$, which is the subject of the next sections. The following section considers the industry mix effect $(M)$. 
TABLE 1: Regional Competitive Share (S), Industry Mix (M), National Share (N) and Total Change in Regional GVA ( $\times$ R1 000), Southern District Municipality

\begin{tabular}{lrrrrrr}
\hline \multicolumn{1}{c}{ SECTOR } & \multicolumn{1}{c}{1996} & \multicolumn{1}{c}{ 2006 } & \multicolumn{1}{c}{$R$} & \multicolumn{1}{c}{$N$} & \multicolumn{1}{c}{$M$} & \multicolumn{1}{c}{$S$} \\
\hline Food \& beverages & 306576 & 273287 & -33289 & 104236 & -70512 & -67013 \\
$\begin{array}{l}\text { Textile \& clothes } \\
\text { Wood \& paper }\end{array}$ & 17404 & 16595 & -809 & 5917 & -2959 & -3767 \\
$\begin{array}{l}\text { Petroleum \& } \\
\text { chemicals }\end{array}$ & 163529 & 32921 & -1608 & 11740 & -1381 & -11967 \\
$\begin{array}{l}\text { Other non-metal } \\
\text { Metal products }\end{array}$ & 144979 & 180650 & 17334 & 55527 & 37563 & -75756 \\
$\begin{array}{l}\text { Electrical } \\
\text { machines }\end{array}$ & 9535 & 145471 & -1062 & 49821 & -4396 & -46486 \\
$\begin{array}{l}\text { Electronic } \\
\text { equipment }\end{array}$ & 9831 & 11299 & 1722 & 3256 & 1532 & -3066 \\
$\begin{array}{l}\text { Transport } \\
\text { equipment }\end{array}$ & 31506 & 38369 & 6863 & 10712 & 10082 & -13931 \\
$\begin{array}{l}\text { Furniture } \\
\text { TOTAL }\end{array}$ & 107703 & 112554 & 4851 & 36619 & 2154 & -33922 \\
\hline
\end{tabular}

Source: Rex Database, (2007) (Authors'own calculations)

\subsection{The Industry Mix Effect (M)}

The industry mix effect shows how the region's industrial structure affects overall production growth in the economy (SETA, 2008:2). The Industry Mix (x Rl 000) in the Southern District Municipality for the period 1996 to 2006 is also provided in TABLE 1.

The change in production due to the region's unique industry mix is represented by the industry mix effect $(M)$, which is defined by the following equation:

$$
\mathrm{M}=\sum_{\mathrm{k}=1}^{\mathrm{n}} \mathrm{MR}_{\mathrm{k}}\left(\mathrm{e}_{\mathrm{tok}}\right)
$$

where $M$ is the regional industry mix, $M R$ is the marginal rate of growth in sectors $1,2,3, \ldots k$ and etok is the region's sectoral production in the initial year.

The industry mix effect is calculated as a product of the region's sectoral production in the initial year and the marginal rate of growth. The marginal rate of growth (MR) is the difference between the national sectoral growth and the national average growth. When local production is concentrated in the fast-growing sectors, the rate of local production growth would exceed the national average. If the regional production were concentrated in slow-growing sectors, the growth rate of regional production would be lower than the national economy-wide average.

A positive industry mix means that the region has firms that are growing faster than the national average growth rate and a negative industry mix would have the opposite effect. TABLE 1 shows that the total regional industry mix equals minus 43461 . This negative regional industrial mix implies that the region has firms that are growing slower than the national average growth rate. Not all sectors are negative, though, and the individual sectors can also be investigated. The regional competitive share effect $(\mathrm{S})$ is discussed next. 


\subsection{The Regional Competitive Share Effect (S)}

The regional competitive share describes how sectors in the region performed relative to the national averages of the same sectors. This is calculated by multiplying the base-year production in each regional sector with the margin between the regional sector's growth rate and the national average growth rate of that sector (SETA, 2008:2). A positive regional competitive share suggests that the region's production in that sector is growing faster than its national counterpart and a negative regional competitive share means that the region's production in that sector is growing slower than its national counterpart.

For the SDM, the regional competitive share effect is provided in the last column of TABLE $\mathbf{1}$. The total change in regional production $(R)$ is defined in equation 1 as:

$$
R=N+M+S
$$

Then $\quad \mathrm{S}=\mathrm{R}-\mathrm{N}-\mathrm{M}$

$$
\begin{aligned}
& =-18537-(29646)-(43461) \\
S & =-271540
\end{aligned}
$$

This figure of minus 271540 suggests that the region's sectors led to a decrease in production. In the case, all the sectors do so because the regional competitive share effects are all negative.

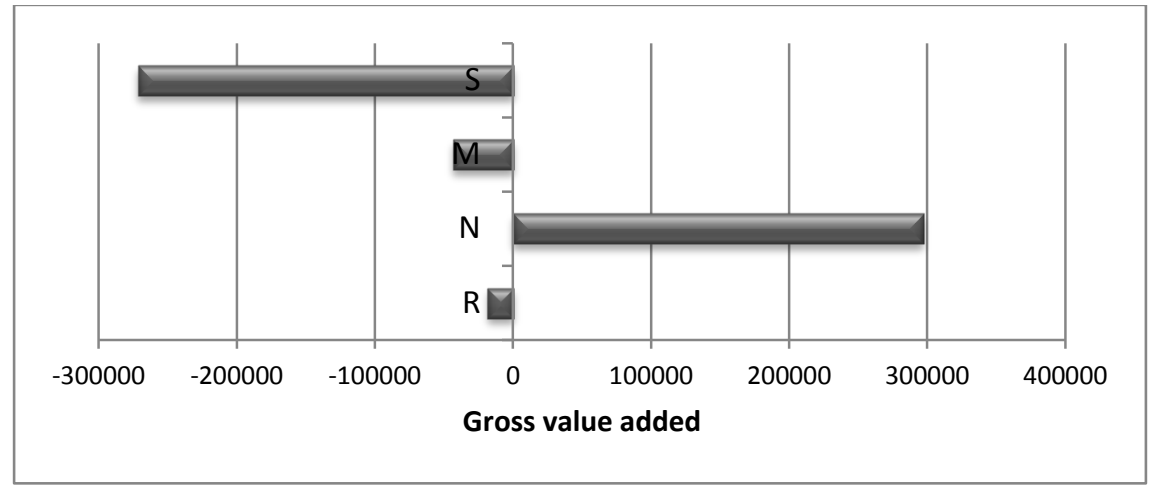

FIGURE 1: Shift-Share Analysis of the Gross Value Added, SDM

Source: Authors'analysis

Regional competitive share effect, industry mix effect, national share effect and total change in regional gross value added $(\times \mathrm{Rl}$ 000) in the Southern District Municipality for the period 1996 to 2006 are all provided in TABLE $\mathbf{1}$ and summarised in FIGURE $\mathbf{1}$. Individual sectors are discussed in the next section.

\subsection{Percentage Contribution Relative to Sector Size}

In order to enable a comparison between sectors, the\% contribution of each effect relative to the size of that particular sector in the SDM was calculated and summarised in TABLE 2.

This also enables the researchers to rank the top performing sectors. Consideration was given to both a high total regional change in GVA and a high percentage contribution. In terms of these criteria, the following sectors are exceptional: transport equipment, petroleum and chemicals, furniture, metal products, and wood and paper products. A look at the total GVA contribution of 
electrical machines indicates a positive total regional change in GVA (R), but TABLE 2 indicates that its percentage contribution to the total GVA is a mere $1 \%$ and therefore does not qualify as a sector with growth potential.

TABLE 2: Percentage Contribution to the Relevant Sectors, SDM

\begin{tabular}{|c|c|c|c|c|c|}
\hline SECTOR & 1996 & $R \% \Delta$ & $N \% \Delta$ & $M \% \Delta$ & $S \% \Delta$ \\
\hline Food \& beverage & 306576 & -11 & 34 & -23 & -22 \\
\hline Textile \& clothes & 17404 & -5 & 34 & -17 & -22 \\
\hline Wood \& paper & 34529 & -5 & 34 & -4 & -35 \\
\hline Petroleum \& chemicals & 163316 & 11 & 34 & 23 & -46 \\
\hline Other non-metal & 44979 & -22 & 34 & -28 & -28 \\
\hline Metal products & 146533 & -1 & 34 & -3 & -32 \\
\hline Electrical machines & 9577 & 18 & 34 & 16 & -32 \\
\hline Electronic equipment & 9831 & -27 & 34 & -30 & -31 \\
\hline Transport equipment & 31506 & 22 & 34 & 32 & -44 \\
\hline Furniture & 107703 & 5 & 34 & 2 & -31 \\
\hline
\end{tabular}

Source: Rex Database, (2007) (Authors'own calculations)

\subsection{Sectoral Analysis}

Analysis of the individual sectors for the Southern District Municipality is undertaken with reference to levels of production ( $\times$ Rl 000) given in TABLE 1 and use was made of equation 1 . For example, the textile and clothes sector has a total change in regional production of minus 809; this is the sum of the national share effect (5917), industry mix effect (-2 959) and the regional competitive share effect $(-3767)$, according to equation 1 :

$$
\begin{aligned}
R & =N+M+S \\
-809 & =[5917+(-2959)+(-3767)]
\end{aligned}
$$

The production for 2006 in this sector is the sum of the 1996 production and the total change in regional production, namely

$$
\begin{aligned}
& =16595=[17404+(-809)] \\
& (=16595 \times \text { R1 } 000-\text { Rand is the South African currency })
\end{aligned}
$$

In the following paragraphs, individual sectors are analysed using the above reasoning.

\subsubsection{Food, Beverages and Tobacco (SIC: 30111-30600)}

Production in the food, beverages and tobacco sector would have been $410812=[306576+$ $104236]$ in 2006 if the sector grew at the national average growth rate (of course $\times$ Rl 000 in each case, thus $=$ R410 812000 ). The actual growth was minus 33289 , which is in essence a decline in production, hence the production for 2006 is $273287=[306576+(-33289)]$ and this is lower than 410812 by minus 137525 . This difference is accounted for by the industry mix effect of minus 70512 and the regional competitive share effect of minus 67013 . Because both are negative, the net effect is a decline in production from 306576 in 1996 to 273287 in 2006. 


\subsubsection{Textile, Clothing and Leather Works (SIC: 3111-31700)}

Production in the textile, clothing and leather works sector would have been 23321 in 2006 if the sector grew at the national average growth rate, but the actual growth is minus 809 , resulting in production of $16595=[17404+(-809)]$. The difference between 16595 and 23321 is minus 6726 and is accounted for by the industry mix and the regional competitive share of minus 6726 $=[-2959+(-3767)]$. The negative effect of the industry mix and the regional competitive share led to a decrease in production from 17404 in 1996 to 16595 in 2006.

\subsubsection{Wood, Paper, Publishing and Printing (SIC: 32101-32600)}

The production of wood, paper, paper products, publishing and printing in 2006 was 32921 , but it would have been $46269=[32921+11740]$ if the sector grew at the national average growth rate. The industry mix and the regional competitive share, minus $13348=[-1381+(-11967)]$, had a negative impact on production, hence the actual 2006 production is 32921 from 34529 in 1996.

\subsubsection{Fuel, Petroleum, Chemicals, Rubber and Plastic (SIC 33100-33800)}

The 2006 production of the sectors of fuel, petroleum, chemicals, rubber and plastic products would have been 218843 had the sector grown at the national average growth rate, but the actual growth is 180650 . Although the total change in regional growth of 17334 is positive, it is less than the national share of 55527 , hence the difference of minus 38 193. This difference is a result of the positive industrial mix (37563) and a negative regional competitive share $(-75756)$. A positive industrial mix reduced the negative impact of the regional competitive share and led to a positive growth in production, albeit smaller than the national share effect, from 163316 in 1996 to 180650 in 2006 . A positive industrial mix means that this sector is growing faster than the national average growth rate.

\subsubsection{Other Non-Metal Mineral Products (SIC: 34111-34299)}

The actual production in the non-metal mineral products sector in 2006 is 35089 . Had the sector grown at the national average growth rate, it would have been 60272 . The difference of minus 25183 between the actual and the expected production is due to the net effect of the industry $\operatorname{mix}(-12594)$ and the regional competitive share (-12 589), which led to a decline in production from 44979 in 1996 to 35089 in 2006.

\subsubsection{Metal, Metal Products, Machinery and Equipment (SIC: 35101-35900)}

Had the metal, metal products, machinery and equipment sector grown at the national average growth rate, the 2006 production would have been 19635 , but it was only 145471 . The industry mix effect of minus 4396 , together with the regional competitive share effect of minus 46486 , is responsible for the difference of minus $50883=[-4396+(-46486)]$. This difference resulted in a drop in production from 146533 in 1996 to 145471 in 2006.

\subsubsection{Electrical Machinery and Apparatus (SIC: 36100-36600)}

Production in the electrical machinery and apparatus sector for 2006 would have been 12833 had it grown at the national average growth rate; but it was 11299 . The positive industry mix effect of 1532 diluted the negative impact of the regional competitive share of minus 3066 , 
resulting in a difference of minus 1534 , which could have been worse had the industry mix been negative. However, production increased, although not as much as it would have had it been according to the national share, from 9577 in 1996 to 11299 in 2006. The positive industry mix suggests that the region has firms in this sector that are growing faster than the national average growth rate.

\subsubsection{Electronic Equipment (SIC: $37100-37600$ )}

Had the sector for electronic equipment grown at the national average growth rate, then production would have increased to 13174 in 2006 from 9831 in 1996. However, the actual production is 7182 , which is lower than 13174 by 5992 . The net effect of the negative industry mix and regional competitive share exacerbated the loss in production.

\subsubsection{Transport Equipment (SIC: $38100-38790$ )}

Production in the transport equipment increased from 31506 in 1996 to 38369 in 2006 and would have been even more $(42218)$ had the sector grown at the national average growth rate. The difference of minus 3849 is due to the combined effects of the positive industrial mix of 10082 and the negative regional competitive share of minus 13931 . The positive industry mix implied that firms in this sector grew faster than the national average growth rate.

\subsubsection{Furniture (SIC: $38100-38790)$}

The actual production of furniture in 2006 was 112554 and it should have been 144322 , according to the national share (of course still $\times$ R1 000 in each case, thus $=$ R144 322000 ). The positive industrial mix contributed to the increase in production and minimised the negative effect of the regional competitive share. Although the growth is not equal to the national share, the presence of firms that grew faster than the national average growth rate counted in favour of the regional growth, hence production increased from 107703 in 1996 to 112554 in 2006.

\section{COMPARISON OF NATIONAL AND PROVINCIAL DATA}

The study was repeated using values relative to provincial data, and the results were not significantly different. Both the national and provincial analyses revealed that the sectors with potential for future development are the sectors for transport equipment, wood and paper products, furniture, metal products and petroleum and chemicals. The authorities in the Southern District Municipality are advised to use available resources to support the development of these sectors.

\section{SHIFT-SHARE ANALYSIS OF EMPLOYMENT IN THE SDM}

A similar study was conducted using employment figures of the various sectors in the SDM region, and similar results were obtained. This confirmed the findings of the research project and indicated the identified industries' potential to create employment opportunities (see Kleynhans \& Sekhobela, 2009). In the empirical analysis of employment, it was found that the total change in national employment was equal to minus 30373 jobs, translating into an average growth rate of minus two per cent, implying a loss of over 30000 jobs in the 
manufacturing industry of the entire country. Total changes in regional employment $(R)$, national share effect $(N)$, industrial mix effect $(M)$ and the competitive share effect $(S)$ are illustrated in FIGURE 2.

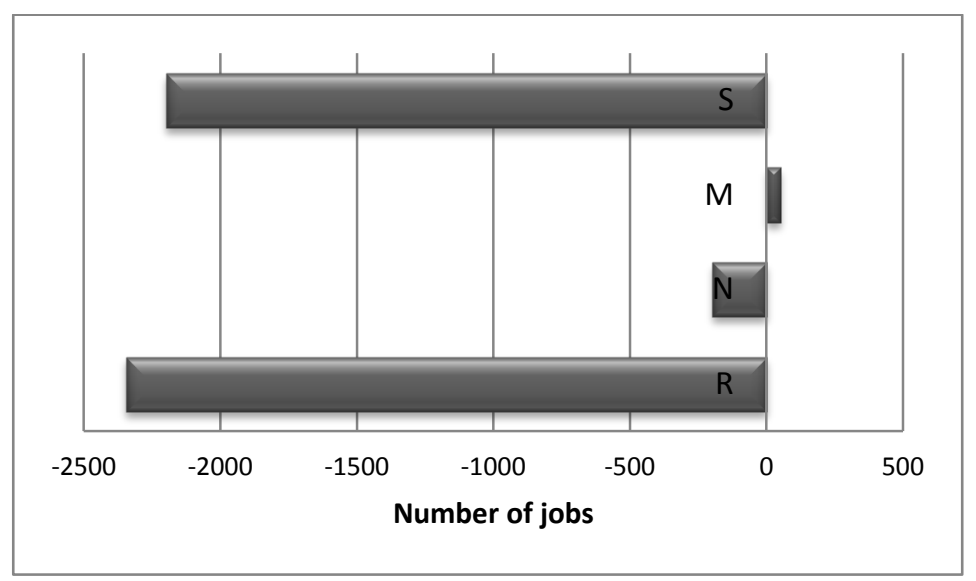

\section{FIGURE 2: Shift-Share Analysis of Employment in the SDM}

\section{Source: Authors'analysis}

FIGURE 2 shows that the total change in regional employment (R) equalled minus 2345 , indicating a loss of over 2000 jobs in manufacturing in the Southern District Municipality. This component is the sum of the national share effect $(N)$, industry mix effect $(M)$ and the competitive share effect $(\mathrm{S})$. The national share effect $(\mathrm{N}$ ) amounted to minus 198 , indicating job losses (see FIGURE 2). This measured the region's potential employment change, assuming that its economy is growing at the national average growth rate.

The industry mix effect (M), which describes how the region's industrial structure fits into the overall employment growth performance in terms of the national average growth rate, indicated a positive figure of 51 for this component. The positive amount of the industry mix effect minimised the total job losses in the region as per the total change in regional employment, which could have been a decline in excess of 2345 were it not for this component. The competitive share effect $(S)$, which explained how sectors in the region performed compared to their national counterparts, indicated a decline of 2 198, which exacerbated the job losses in the region.

The sectoral ranking indicates sectors that had future growth potential based on the percentage contribution of each sector to the total regional change in employment and the sector's relative size of employment (percentage of total employment represented by a sector). Overall results indicate that $50 \%$ of the sectors in manufacturing have the potential for future growth and development. The sectors with the highest employment creation potential are transport equipment, wood and paper products, metal products, furniture, and petroleum and chemicals.

The study also considered the shift-share analysis changes of manufacturing in the SDM by comparing the industries in the region to national and provincial data. As in the case of valueadded and employment data, it also confirmed the research findings. 


\section{SUMMARY AND CONCLUSION}

This study investigated the development, structure and dynamics of production in the manufacturing industries of the Southern District Municipality (SDM) of South Africa, using the methodology of shift-share analysis. As an alternative, productivity or competitiveness indexes could have been estimated for the various sectors in the region (e.g. Kleynhans, 2006), or viable clusters could have been identified (e.g. Suleman, 1998), or micro-economic optimal location estimates could be determined. This might be advisable for further research, especially if those indexes are based on information obtained from new industrial surveys. Shift-share analysis was, however, preferred for this study because its results are easy for policymakers to comprehend and apply. The technique reveals spatial shifts of value-added production output in the context of the economic geography over time. It also breaks this down into the individual sub-sectors and reveals specific effects that explain these dynamics. It indicates the national effect on production in the region, as well as the effects of the region's industrial mix and competitive share on production. The academic merit of this article lies in the illustration of the practical application of most theories found in Spatial Economics and Economic Geography, in an easy manner, applying the technique of shift-share analysis.

The rationale for this study was the fact that the SDM region, which was highly dependent on gold mining and production, is declining as its gold reserves are becoming depleted. This trend has persisted over a long period. Spadavecchia (2007:44) reports that the total mining production for the three months ending in July 2007, after seasonal adjustment, decreased by $1 \%$ compared to the previous three months. According to Stats SA, this was owing to a decrease of $1.7 \%$ in the production of gold and a decrease of $0.9 \%$ in the production in non-gold minerals. Gold production from January 2008 to January 2009 declined by $12.2 \%$ (Stats SA, 2009:3). In 2005, nine mines employing 69061 workers and producing 125 tonnes annually were in a marginal or loss-making position. This means that a large section of the people in the area will be unemployed in the near future if this and other accompanying development needs are not addressed in time. This study aimed at identifying industries that offer potential for future growth.

The traditional and static shift-share analysis method was used. Data restrictions were circumvented by applying this method to the Rex database of Global Insight, which has annual data on local and district municipalities, at provincial and national levels. The national and provincial analyses arrived at similar results for the total change in regional change in gross value added. Total change in regional production output (gross value added) is the sum of national share effect, industry mix effect and regional competitive share effect. The industry mix effect and the regional competitive share effect have a direct impact on the national share.

The sector for petroleum, fuel, chemicals, and rubber and plastic products experienced the highest production output rate according to total figures, followed by transport equipment, furniture and electrical machines. These were the only sectors experiencing overall positive growth. When the relative size of the particular sector is also considered, the metal products sector joins the top five.

On the other hand, the non-metallic products sector experienced the worst production losses in relation to most sectors, considering both absolute figures and the relative size of individual sectors. However, in relation to competitive share effects in this region, the sectors for textiles and clothing, food and beverages and other non-metallic products are in the top three positions, in that order. 
In relation to the industrial mix in this region, transport was second best, with petroleum and chemicals in the first place, furniture and fuel third and electrical machines fourth. These sectors were the only ones able to expand production output during the research period. Due to the industrial mix of the region, production in all the other sectors declined. The national share effect was to the advantage of all sectors. In relation to all the various effects, the electronic equipment sector is wanting when it comes to the creation of employment and value-added production output growth, and it does not deserve much attention.

Finally, the top five sectors have strong growth potential, but in relation to their regional competitive share effect, it is worrying that petroleum and chemicals were in the last place, and transport equipment second to last, while the sectors for electrical machines and metal products only ranked sixth and seventh. This implies that the regional industrial mix effect had to be much stronger to enable them to experience growth.

To summarise, this study found that the sectors with the highest growth potential in the SDM region are transport equipment, petroleum and chemicals, furniture, metal products, and wood and paper products, and they merit attention in future development initiatives. When the relative sizes of the individual sectors are taken into consideration, the electrical machines sector moves into the second place, replacing wood and paper products, and furniture moves up one place among these top performers. These top performers merit attention in future development initiatives.

This was the first phase in investigating the problem of mines becoming redundant, resulting in unemployment and other under-development problems in the SMD. The next step will be to conduct an in-depth study of these sectors and estimate multipliers that could provide further information on their future performance potential. Further research may also consider the influence of neighbouring regions and the development of better empirical methods to model this. A thorough literature study was conducted above to illustrate the importance of shiftshare analysis and to delineate a further programme of research.

\section{Authors' note}

This article is based partially on a paper delivered at the 2008 International Conference for Business, in Honolulu, Hawaii. Recommendations were incorporated.

\section{REFERENCES}

Armstrong, H. \& Taylor, J. (2000). Regional Economics and Policy, $3^{\text {rd }}$ edition. Oxford: Blackwell.

Armstrong, H. \& Taylor, J. (1993). Regional Economics and Policy. New York: Harvester.

Ashby, L.D. (1964). The Geographical Redistribution of Employment: An Examination of the Elements of Change, Survey of Current Business, 44, pp. 3-20.

Bendavid-Val, A. (1993). Regional and Local Economic Analysis for Practitioners. New York: Prager.

Borts, G.H. \& Stein, J.L. (1964). Economic Growth in a Free Market. New York: Columbia University Press.

Brown, H.J. (1969). Shift-Share Projections of Regional Growth: Empirical Test. Journal of Regional Science, 9, pp. 1-18. 
Chamber of Mines of South Africa. (2005). Facts \& figures 2005. Marshalltown: Chamber of Mines. Chapman, K. \& Walker, W.F. (1991). Industrial location: Principles and policies. Oxford: Basil Blackwell.

Dinc, M. \& Hayes, K. (2005). Productivity, International Trade and Reference Area Interactions in Shift-Share Analysis: Some Operational Notes, Growth and Change, 36(3), pp. 374-394.

Drewes, J.E. \& Kleynhans, દ.P.J. (2008). The Influence of Location on the International Competitiveness of South African Industries, Journal of Economic and Financial Sciences, 2(2), pp. 139-158.

Dunn, E.S. (1960). A Statistical and Analytical Technique for Regional Science. In: B.H. Stevens, \& C.L. Moore. (1980). Journal of Regional Science, 20(4), pp. 419-437.

Dyason, D. (2005). Manufacturing Exports and Transport Costs from South Africa's Secondary Cities. Unpublished M.Com dissertation. Potchefstroom: North-West University.

Esteban-Marquillas, J.M. (1972). A Reinterpretation of Shift-Share Analysis. Regiona/ and Urban Economics, 2, pp. 249-255.

Fernández, M.M. \& Menéndez, A.J. (2006). Spatia/ Shift-Share Analysis: New Developments and Some Findings for the Spanish Case. Paper read at the $45^{\text {th }}$ Congress of the European Regional Science Association.

Fujita, M., Krugman, P. \& Venables, A.J. (2001). The Spatial Economy. Cities, Regions and Internationa/ Trade. Cambridge: MIT Press.

Global Insight.(Southern Africa). (2007).Rex-Database. Available from: http://www.globalinsight.co.za. (Accessed 7 February 2011)

Golley, J. (2002). Regional Patterns of Industrial Development during China's Economic Transition, Economics of Transition, 10(3), pp. 761-801.

Graham, D.J. \& Spence, N. (1998). A Productivity Growth Interpretation of the Labour Demand ShiftShare Model, Regional Studies, 32(6), pp.515-525.

Hellman, D.A. (1976). Shift-Share Models as Predictive tools, Growth and Change, 7, pp. 3-8.

Hellman, D.A. (1974). Agglomeration Economies: A Model of Regional Export Activity, Growth and Change, 5, pp.12-17.

Hewings, G.J.D. (1976). On the Accuracy of Alternative Models for Stepping-Down Multi- Country Employment Projections to Countries, Economic Geography, 52, pp. 206-217.

Isard, W. \& Liossatos, P. (1979). Spatial Dynamics and Optimal Space-Time Development. New York: North Holland Publishing.

James, F. \& Hughes, J. (1973). A Test of Shift and Share Analysis as a Predictive Device, Journal of Regional Science, 13, pp. 223-231.

Jansen, I. (2007). Stilfontein - Healed, but Scars Remain, Solidarity, 5, p. 30.

Kleynhans, E.P.J. (2006). The Role of Human Capital in the Competitive Platform of South African Industries, South African Journal of Human Resource Management, 4(3), pp. 55-62.

Kleynhans, E.P.J. \& Drewes, J.E. (2008). The Influence of Location on the Efficiency of Manufacturers in South Africa, Town and Regional Planning, 53, pp. 1-8. 
Kleynhans, દ.P.J. \& Sekhobela, M.J. (2009). Shift-Share Analysis of Manufacturing as a Measuring Instrument for Human Resource Management, South African Journal of Human Resource Management, 7(3), pp. 14-21.

Kleynhans, E.P.J., Naudé, W.A. \& Van Der Merwe, S.J. (2003). Spatial Economic Development in South Africa: An Overview and Evaluation of the Platinum Spatial Development Initiative. Development Southern Africa. 20(5), pp. 617-631.

Kobayashi, N. \& Roper, S. (2004). Industria/ Structure and Manufacturing Growth during Japan's Bubble and Post-Bubble Economies, Regional Studies, 38(4), pp. 429-444.

Krugman, P. (1991). Geography and Trade. Cambridge: MIT.

Lösch. A. (1954). Economics of Location. New Haven: Yale University Press.

Lann, R. (2005). Shift-Share Analysis: Mix and Share Analysis. Georgia: Economic Development Institute. Georgia Institute of Technology (Georgia Tech). Available from:

http://www.cherry.gatech.edu/6602/PRESENT/shift-share\%20analysis.ppt\#6. (Accessed 16 April 2010)

Mankiw, N.G. (2007). Principles of Microeconomics. Mason: Thomson

Maia, J. (2009). Interview on 18 August 2009 with Jorge Maia, the Head of Research, of the Industrial Development Corporation.

Mayor, M. \& López, A.J. (2008). Spatial Shift-Share Analysis versus Spatial Filtering: An Application to Spanish Employment Data, Empirical Economics, 34, pp.123-142.

Mayor, M., López, A.J. \& Pérez, R. (2007). Forecasting Regional Employment with Shift-Share and ARIMA Modelling, Regiona/ Studies, 41(4): 543-551.

Mollick, A.V., Cortez-Rayas, A. \& Olivas-Moncisvais, R.A. (2006). Local Labor Markets in U.S.-Mexican Border Cities and the Impact of Maquiladora Production, The Annals of Regional Science, 40, pp. 95116.

Nazara, S. \& Hewings, G.J.D. (2004). Spatial Structure and Taxonomy of Decomposition in Shift-Share Analysis, Growth and Change, 35(4): 476-490.

Patterson, M.G. (1991). A Note on the Formulation of a Full Analogue Regression Model of the ShiftShare Method, Journal of Regional Science, 31(2), pp. 211-216.

Peh, K. \& Wong, F. (1999). Growth in Singapore's Export Markets, 1991-96: A Shift-Share Analysis. Asian Economic Journal, 13(3), pp. 321-340.

Perloff, H.S., Dunn, E.S., Lampard, દ.E. \& Muth, R.F. (1960). Regions, Resources and Economic Growth. Lincoln, Nebraska: University of Nebraska Press.

Ray, M.A. (1995). Employment in the $\varepsilon C, \varepsilon F T A$, and the $\varepsilon \varepsilon A:$ A Regional Analysis, Journal of Economics and Finance, 19(2), pp. 19-28.

Rosenfeld, F. (1959). Commentaire à l'Exposé de M. Dunn. Economic Appliquée, 4, pp. 531-534.

SETA. (2008). The Shift-Share Analysis for Adair county, Office of Social \& Economic Trend Analysis. lowa: USA. Available from:

http://www.seta.iastate.edu/takecharge/shiftshare.aspx?state=|A\&fips=19001\&cityfips=. (Accessed 15 April 2008)

Shearmur, M. \& Polèse, M. (2007). Do Local Factors Explain Local Employment Growth: Evidence from Canada, 1971-2001, Regiona/ Studies, 41(4), pp. 453-471. 
Southern District Municipality.(2007). Southern District Growth and Development Strategy Review. Southern District Municipality: Klerksdorp.

Spadavecchia, 0. (2007). SA Gold Output Fell 5,2\% y-on-y in July, Mining Weekly, 11 September 2007, 15, pp. 44.

Statistics South Africa (Stats SA). (2010). Statistical release P2041 Mining: production and sales (Preliminary). January 2010. Pretoria: Statistics South Africa.

Statistics South Africa (Stats SA). (2009). Statistical release P2041 Mining: production and sales. Pretoria: Statistics South Africa.

Statistics South Africa (Stats SA). (2007). Statistical release P2041 Mining: production and sales. Pretoria: Statistics South Africa.

Statistics South Africa (Stats SA). (2006). Provincial profile 2004: North West Report No. 00-91-06 (2004). Pretoria: Statistics South Africa.

Stevens, B.H. \& Moore, C.L. (1980). A Critical Review of the Literature on Shift-Share as a Forecasting Technique, Journal of Regional Science, 20(4), pp. 419-437.

Stilwell, F.J.B. (1969). Regional Growth and Structural Adaptation, Urban Studies, 6, pp. 162-178.

Suleman, A. (1998). The Competitiveness and Comparative Advantages of South Africa's Manufacturing Sector with Reference to the Provinces. Unpublished PhD thesis. Potchefstroom: Potchefstroom University for Christian Higher Education.

Van Der Merwe, J. (2006). Shift-Share Analysis: An Alternative Study of Regional Growth with Panel Data. Unpublished B.Com Honours mini-dissertation. Potchefstroom: North-West University.

Weber, A. (1929). Theory of Location of Industries. Chicago: University of Chicago Press.

Wheeler, J.0. \& Muller, P.0. (1998). Economic Geography. New York: John Wiley.

Wilson, P., Chern, T.S., Ping T.S. \& Robinson, E. (2005). Assessing Singapore's Export Competitiveness through Dynamic Shift-Share Analysis, Asian Economic Bulletin, 22(2), pp. 160-185.

Zimmerman, R. (1975). A Variant of the Shift and Share Projection Formulation, Journal of Regional Science, 15, pp. 29-38. 